\title{
RICHNESS AND ENDEMISM OF THE FRESHWATER FISHES OF MEXICO
}

\section{Topiltzin Contreras-MacBeath ${ }^{1}$, Marlem Brito Rodríguez ${ }^{2}$, Valentino Sorani ${ }^{3}$, Chris Goldspink ${ }^{4}$ \& Gordon McGregor Reid ${ }^{5}$}

${ }^{1}$ Centro de Investigaciones Biológicas, Universidad Autónoma del Estado de Morelos, México

${ }^{2}$ Facultad de Ciencias Biológicas, Universidad Autónoma del Estado de Morelos, México

${ }^{3}$ Centro de Investigación en Biodiversidad y Conservación, Laboratorio Interdisciplinario de Sistemas de Información

Geográfica, Universidad Autónoma del Estado de Morelos, C.P. 62260, Morelos, México

${ }^{4}$ Manchester Metropolitan University, All Saints Building, All Saints, Manchester, M15 6BH, UK

${ }^{5}$ Chester Zoo, Upton-by-Chester, Chester $\mathrm{CH} 2$ 1LH, UK

${ }^{1}$ topis@uaem.mx (corresponding author), ${ }^{2}$ merlam_14@hotmail.com, ${ }^{3}$ vsorani@yahoo.com.mx,

${ }^{4}$ CGoldspink@aol.com, gordonr@chesterzoo.org
Abstract: A study of richness and endemism of the freshwater fishes of Mexico, was carried out in order to identify hotspots and inform conservation efforts. This was done by mapping and overlaying individual species distributions by means of geographical information systems based on museum data. The study was able to confirm several previously proposed centres of freshwater fish richness (Southeastern Mexico, the Mesa Central, the Bravo-Conchos river system and the Panuco and Tuxpan-Nautla rivers). Seven areas with high 'Corrected Weighted Endemism' Index values were identified, with the valley of Cuatrociénegas recognized as a true centre. An alarming result was the identification of a "Ghost" centre of endemism (Llanos El Salado) in southwestern Nuevo León, where six endemic cyprinodont species are all 'extinct' or 'extinct in the wild'. Forty-nine single site endemics that are distributed all over Mexico were identified. The Chichancanab lagoon in the border between Yucatan and Quintana Roo, where a flock composed of six endemic cyprinodonts is present needs special mention. Three hotspots of richness plus endemism were found in Mexico, the most important of which is the Mesa Central where impacts by human activities have had a detrimental effect on fish populations.

Keywords: Conservation, hotspots, ichthyodiversity, Meso-America, species.

Spanish Abstract Resumen: Se realizó un estudio de la riqueza y endemismo de los peces dulceacuícolas de México, con la finalidad de identificar "hotspots" y dirigir esfuerzos de conservación. Lo anterior se llevó a cabo mediante el mapeo y la superposición de las distribuciones de especies con el uso de sistemas de información geográfica y bases de datos de colecciones científicas. Los resultados confirman varios centros de endemismos propuestos previamente (Sudeste mexicano, la Mesa central, el sistema Bravo-Conchos, así como el de los ríos Panuco y Tuxpan-Nautla). Se identificaron además siete áreas con altos valores en el Índice de Endemismo Ponderado, siendo el Valle de Cuatro Ciénegas un verdadero Centro. Un resultado alarmante fue el haber encontrado un centro de endemismo "fantasma" (Llanos El Salado) al Sudoeste de Nuevo León, donde seis especies de Cyprinodóntidos endémicos están ahora extintos o extintos en la naturaleza. Se encontraron además cuarenta y nueve especies endémicas a una sola localidad. Destaca el caso de la laguna de Chichancanab ubicada en la frontera de los estados de Yucatán y Quintara Roo, donde existe un grupo compuesto de seis especies de Cyprinodóntidos. Se encontraron tres "hotspots" de riqueza y endemismo, dentro de los que destaca la Mesa central, donde los impactos de las actividades humanas han tenido un fuerte impacto sobre las poblaciones de peces.

DOI: http://dx.doi.org/10.11609/JoTT.03633.5421-33 | ZooBank: urn:Isid:zoobank.org:pub:6D0D9D42-7628-4BFB-9273-48A8A32D4700

Editor: Rajeev Raghavan, Conservation Research Group (CRG), St. Albert's College, Kochi, India.

Date of publication: 26 February 2014 (online \& print)

Manuscript details: Ms \# 03633 | Received 22 May 2013 | Final received 06 February 2014 | Finally accepted 08 February 2014

Citation: Contreras-MacBeath, T., M.B. Rodríguez, V. Sorani, C. Goldspink \& G.M. Reid (2014). Richness and endemism of the freshwater fishes of Mexico. Journal of Threatened Taxa 6(2): 5421-5433; http://dx.doi.org/10.11609/JoTT.03633.5421-33

Copyright: (C) Contreras-MacBeath et al. 2014. Creative Commons Attribution 3.0 Unported License. JoTT allows unrestricted use of this article in any medium, reproduction and distribution by providing adequate credit to the authors and the source of publication.

Funding: Mexican Education Ministry through PROMEP and the Noth England Zoological Society.

Competing Interest: The authors declare no competing interests.

Author Contribution \& Author Details: see end of this article.

Acknowledgements: We would like to thank CONABIO for providing access to their databases, as well as the GBIF for their records.
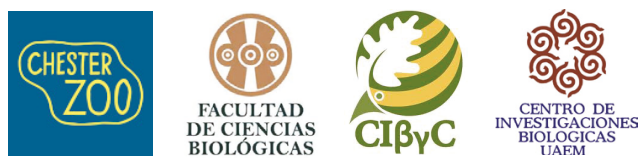

prome

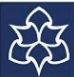




\section{INTRODUCTION}

Mexico is the southern most country of North America, extending into the Isthmus of Tehuantepec. It has a total area of $1,964,375 \mathrm{~km}^{2}$ and is bounded by a coastline of $7,828 \mathrm{~km}$ to the west (Pacific) and $3,294 \mathrm{~km}$ to the east, which includes parts of the Gulf of Mexico and the Caribbean (CNA 2008). The country has a wide range of terrestrial habitats and formations consisting of volcanic mountain ranges and extensive arid deserts, and is estimated to contain at least $10 \%$ of the known world terrestrial biodiversity including plants, reptiles, amphibians and mammals (Espinosa et al. 2008). This taxonomic diversity reflects the wide range of habitats represented in Mexico, regional differences in climate and its position between the Nearctic and Neotropical biogeographical regions (Morrone 2005).

Similarly, a wide range of aquatic systems occurs across the country with over 50 large rivers and 70 large lakes represented. The rivers Yaqui, Fuerte, Mezquital, Lerma-Santiago, and Balsas drain into the Pacific, whilst the Bravo, Pánuco, Papaloapan, Grijalva and Usumacinta rivers drain into the Gulf of Mexico (Lara-Lara et al. 2008). There are over 70 lakes ranging in size from 10-100 $\mathrm{km}^{2}$. Lake Chapala in Jalisco is the largest lake, followed by Cuitzeo and Pátzcuaro in Michoacán, Catazajá in Chiapas, del Corte in Campeche, Bavicora and Bustillos in Chihuahua, and Catemaco in Veracruz. Though, there have been various studies on the distribution of plants and animals across the country (Ramamoorthy et al. 1993, Flores-Villela \& Gerez 1994, Koleff \& Soberón 2008) there have been relatively few studies on aquatic biota (Domínguez-Domínguez et al. 2006b; Huidobro et al. 2006; Aguilar-Aguilar et al. 2008). The freshwater fish fauna is particularly diverse with more than 616 species described of which 264 are endemic (examples of some Mexican freswater fish species are shown in images 1-7). A further 115 species are known to be exotics (Miller et al. 2009). In spite of this diversity there have been very few attempts to formally describe regional differences in fish species assemblages to better inform conservation action.

In this study, we attempt to identify and define regional differences in biodiversity in terms of the 'hotspot' approach which has proved successful in identifying areas of conservation importance elsewhere in the world (Myers 1988, 1990; Myers et al. 2000). Both species number (richness) and endemism are used in defining the 'hotspot' approach by combining two independent measures of biodiversity. Myers (2003) had stressed that "there is an urgent need to document freshwater ecosystems which could prove to be one of the most species-rich hotspots, certainly in terms of fish and one of the most severely threatened of all hotspots". Freshwater ecosystems therefore provide ideal candidates for applying the biodiversity hotspot approach (Mittermeier et al. 2010).

Thus, the main aim of the current study was to reevaluate the status of freshwater fishes in Mexico in terms of their species richness and degree of endemism, and identify and map local 'hotspots' to further direct conservation planning and debate in the country. Largescale studies of this kind on freshwater fish have largely been confined to Brazil and Africa (Nogueira et al. 2010; Darwall et al. 2011).

\section{METHODS}

The analysis used during this study was based on the geographical procedures employed by Aguilar-Aguilar et al. (2008). This consisted of developing geo-referenced distribution records for the freshwater fishes found in Mexico. Empirical data were derived from the National Mexican Biodiversity Authority (CONABIO) and records held by the Global Biodiversity Information Facility (GBIF). These sources yielded 36,174 countrywide records and maps for 563 of the 650 known species listed for the country. These data, which account for ca. $86 \%$ of the total fish fauna, also included many of the introduced or exotic species (Contreras-MacBeath 2014).

For each species, spatial records were converted to a vector format using ArcGis 9.3 and superimposed onto a 1:4,000,000 scale map of Mexico obtained from the geo-information module of CONABIO. Each map was then compared to previously published species accounts (Miller et al. 2009) and those mentioned in Fishbase (Froese \& Pauly 2010) to eliminate inconsistencies and false positives (Fielding \& Bell 1997). Of the total records examined, 358 were rejected representing $1 \%$ of the total. A grid map of Mexico was then produced consisting of 249 grid cells assigned 1-31 from west to east and from $A$ to $M$ North to South. Each $1^{\circ} \times 1^{\circ}$ grid cell equivalent to $12,345 \mathrm{~km}^{2}$ was subsequently converted to raster format. This marker allowed a comparison of the geographical layers. Once the grid was obtained, each grid-cell was assigned consecutive numbers from 1 to 249.

For evaluation, data of each species was transformed to raster format, obtaining a matrix in binary format, with grid-cells with a value of " 1 " where the species was 
present and " 0 " where it was not. This grid was then combined with the distributional ranges of each species using the "combine" command of Arc Info 7.0, which from a series of rasters, creates a new one that shows in its database all the possible combinations among all the rasters used in the operation.

The end result was a coverture in matricial format with an associated table that contains 534 columns, each representing a species, and 249 lines that represent gridcells. In this way, presence and absence information was available for every species in each grid-cell. The total for each line represented species richness in each grid-cell, while the total for each column indicated the distributional range for each species. With this information, a map of Mexico was constructed showing species richness in three categories: Low (1-30 species), medium (31-60 species) and high (61-90 species).

The endemism analysis was based on the 'Corrected Weighted Endemism' Index CWEI (Crisp et al. 2001; Linder 2001; Aguilar-Aguilar et al. 2008) using 216 of the 264 known Mexican endemic species, because of the availability of point data. To calculate the Weighted Endemism Index (WEI), each species was weighted for the inverse of its range such that each endemic species in a grid-cell had a maximum 'weight' of 1 ; if a species was present in three grid-cells, it has a weight of 0.33 and one in 30 grid-cells has a weight of 0.03 . To calculate the value for each grid-cell, the weight values for all the species in that grid-cell was added so that cells with a high number of restricted range species had a higher score than grid-cells with fewer restricted range species (Linder 2001). To correct for the correlation with species richness, and to generate the CWEI, the 'weighted' endemism was divided by the total number of species in a grid-cell (Crisp et al. 2001). A map that differentiates between areas of low, moderate and high endemism was subsequently produced with the results of this analysis.

Due to the fact that the former is a coarse analysis that considers relatively large areas, and that it is known that some Mexican freshwater fish species have highly restricted distribution ranges that would not be identified by this means, we further analyzed single site endemics (extant species) separately, so as to have a finer view of endemism.

To identify possible conservation 'hotspots' of richness plus endemism, the two previous maps were combined by creating two raster maps both with the same grid size, a grid position, and the same georeference, the first for species richness and the second for species endemism. A cross operation was performed by overlaying the two raster maps by comparing cells at the same positions in both maps and keeping track of all the combinations that occur between the values or classes in both maps. A cross-table and the output cross-map were obtained. The results were stored in an output cross-table and an output cross-map. In the table associated with the output raster, a new item was created containing a unique value for all the possible combinations of the two input classes, as well as the class number and description of the first input map (richness) and those of the second input map (endemism) which makes it possible to identify every single combination. The number of pixels occurring for each combination was counted, as well as the areas of the combinations calculated. A biodiversity quality indicator was then defined by assigning to every combination a value, following the decision rule:

$$
\begin{gathered}
\text { IF } V_{r}+V_{e}<4 \text { then } B Q I=\text { poor else if } 4 \leq V_{r}+V_{e} \leq 5 \text { then } \\
B Q I=\text { medium else } B Q I=\text { high }
\end{gathered}
$$

This provided the basis for the production of a map, which correlates richness and endemism.

\section{RESULTS AND DISCUSSION}

\section{Distribution and range}

Fish species records were obtained from 235 of the 249 grid-cells covering Mexico which represented 94.3\% of the country area. Those areas without confirmed records are shown in Figure 2 as white squares and are generally associated with arid regions of country, namely the provinces of El Salado and Mapimi.

In terms of distribution patterns, species varied from having very restricted distributions occurring in only one grid cell (23.3\% of the total) up to those, which were widely represented across the country (Fig. 1 ). Ten species are represented in 45 to 66 of the grid cells, namely Astyanax aeneus (66 cells), Astyanax mexicanus (65), Micropterus salmoides (62), Poecilia mexicana (60), Poecilia sphenops (55), Gambusia affinis (54), Lepomis macrochirus (51), Oreochromis mossambicus (47), Heterandria bimaculata (46) and Sphoeroides annulatus (45). Astyanax aeneus was the most widely represented species, occurring in 66 cells equivalent to ca. $491,093 \mathrm{~km}^{2}$ or $26.5 \%$ of the country area.

Many of the widely dispersed species correspond to the distribution maps previously described by Miller et al. (2009) and Froese \& Pauly (2010), reflecting natural geographical boundaries. These species include Astyanax aeneus, Astyanax mexicanus, Poecilia mexicana, Sphoeroides annulatus and possibly Poecilia sphenops, if sites with populations of un-determined 
taxonomic status are included (Miller et al. 2009). Other widely distributed species are those, which are known to be associated with human activities, especially aquaculture. The Cichlid Oreochromis mossambicus (commonly referred to as Mozambique Tilapia) is now the seventh most widely distributed freshwater fish in Mexico. In addition, four native species, which have had relatively small original distributions in Mexico, have now been translocated to many other parts of the country. Species such as Micropterus salmoides and Lepomis macrochirus have both been widely stocked for sport fishing (Contreras-MacBeath et al. 1998) and Gambusia affinis is often used for the control of mosquito larvae (Miller et al. 2009). Similarly, Heterandria bimaculata has spread through aquaculture activities (ContrerasMacBeath et al. 1998). It is alarming that half of the ten most widely distributed freshwater fishes of Mexico are exotics (Gozlan et al. 2010).

In contrast, 124 species (23.3\% of the total) have ranges restricted to only one cell. Most of these restricted species are from five families comprising $67 \%$ of the total namely, Poeciliidae (19 spp), Atherinopsidae (16 spp), Cyprinodontidae (12 spp), Cyprinidae (11 spp) and Goodeidae (9 spp).

When examined by their range areas, it is apparent that the overall pattern for all species is skewed to the right (Fig. 1), consistent with the generalized model described by Gaston (1998). That is, most species have a relatively small range size and a few have relatively large range size. This pattern has been observed for many other taxonomic species assemblages (Bell 2001; Jetz \& Rahbek 2002).

For Mexico, Ceballos (2001) found that that $50 \%$ of mammal species and $8 \%$ of birds could be considered as 'rare' based on the criterion $\left(50,000 \mathrm{~km}^{2}\right)$ employed by IUCN. Similar results were found for reptiles and

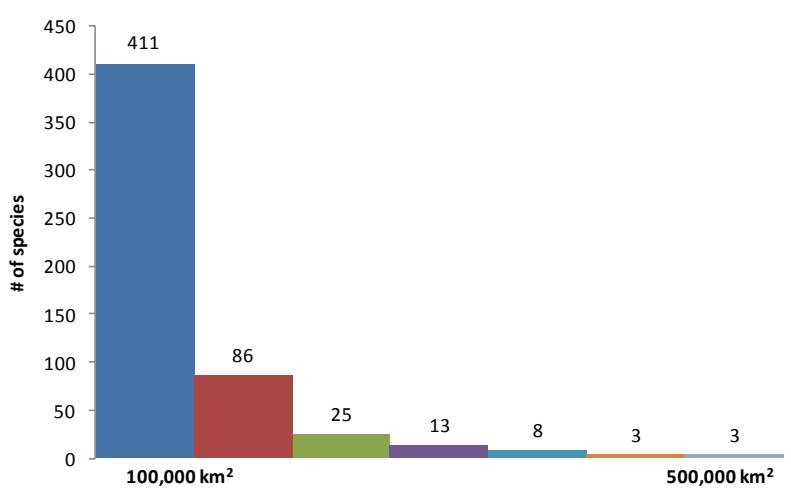

Figure 1. Range size for Mexican freshwater fishes amphibians (Ceballos 2001), which correspond to the value, observed here for fish. Thus based on the $50,000 \mathrm{~km}^{2}$ criterion, $57 \%$ of Mexican freshwater fish should be considered as rare.

Moreover, if each $1^{\circ}$ grid cell is equivalent to $12,345 \mathrm{~km}^{2}$, then 100 species found within this category (19\%) roughly fit the criterion of 'restricted range' species proposed by Nogueira et al. (2010) who found that of the 2587 freshwater fish species known for Brazilian freshwaters, 819 (32\%) had distribution ranges not exceeding $10,000 \mathrm{~km}^{2}$. Similar to Brazil, these values could be used in the identification of site-scale conservation priorities in Mexico.

\section{Richness}

The number of fish species found across the 249 grid cells varied from one up to 90 species per cell with an overall mean of 19 species per cell (Fig. 2). In terms of richness, the grid-cell with the highest richness $(S=90)$ was located in south-eastern Mexico within the Papaloapan River basin. This includes Lake Catemaco, los Tuxtlas (Biosphere Reserve) and the coastal lagoon of Sontecomapan in the State of Veracruz. Of the 90 species recorded, six were exotics, especially tilapias introduced for aquaculture. The 86 remaining species were distributed amongst 27 families, the most speciose of which were Poeciliidae with 18 and Cichlidae with 10. Both these groups represent $32 \%$ of the total fish diversity in the grid-cell.

If families are grouped according to Myer's (1949) classification of freshwater fish based on their tolerance to salt water (primary, secondary and 'peripheral') (Berra 2007), 'peripheral' families dominate, with 22 families and 50 species, while there are only two primary families with five species and three secondary families with 29 species. This clearly reflects the influence of the paleogeographical history of the region, as well as marine radiations and incursions into the freshwater fish fauna (Myers 1966; Miller et al. 2009). This is consistent with what has also been described for the whole of North America (Lévêque et al. 2008).

From Fig. 2, it is evident that the highest values of species richness are found in four distinct centers formed by grid cells which correspond well with the ichthyofaunal provinces described earlier by Miller et al. (2009).

(1) The first center is localized in southeastern Mexico, with the largest number of species per gridcell (62-90) concentrated in the Grijalva-Usumacinta, Coatzacoalcos and Papaloapan rivers (darkest color in the map). This region corresponds with the area of 


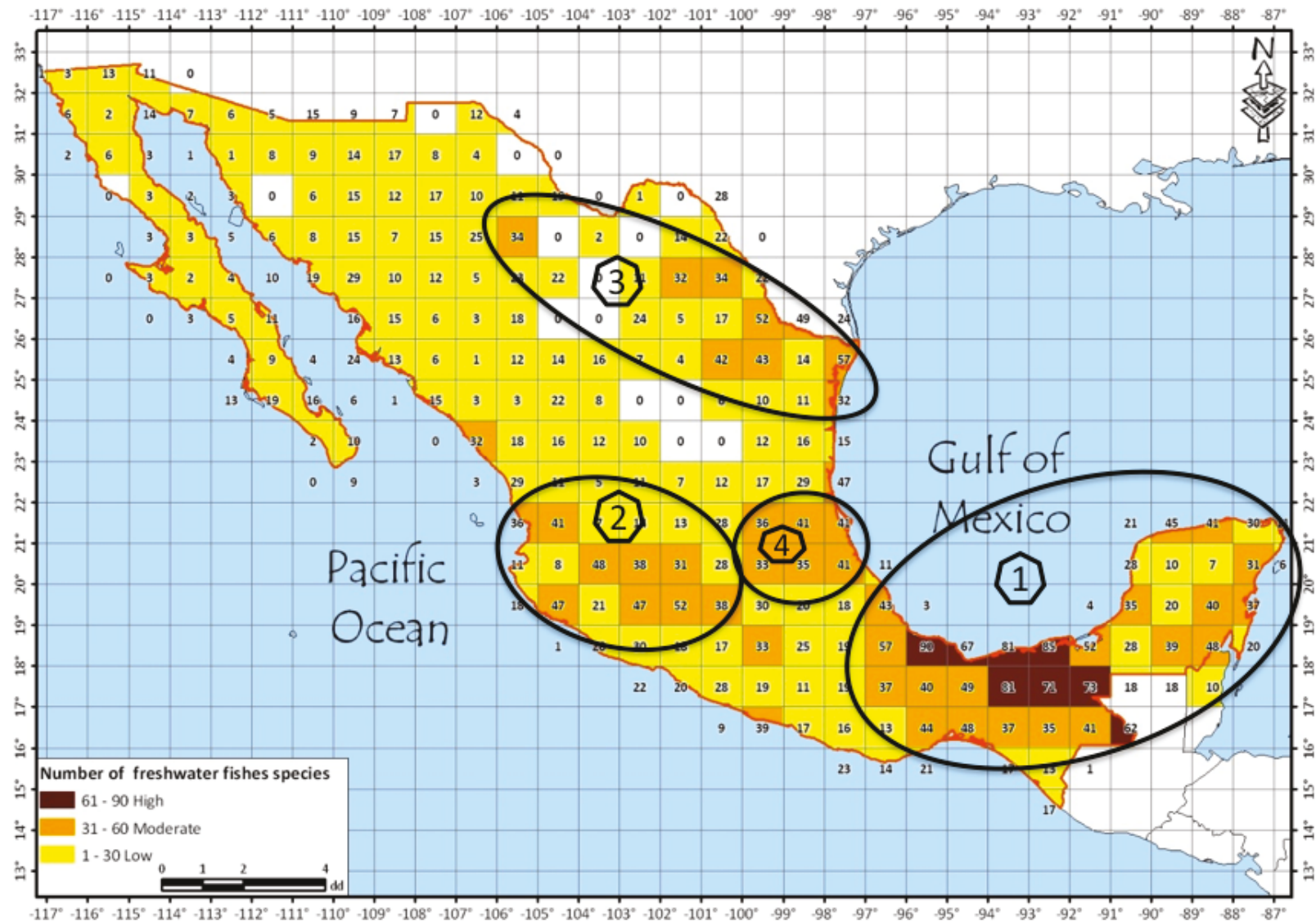

Figure 2. Richness of the freshwater fishes of Mexico. Numbers represent species in each grid-cell. Circles represent centers of richness.

highest availability of water in Mexico (Bunge 2010). If the Yucatan Peninsula is included in this centre, 39 grid-cells are represented and this corresponds to the Usumacinta ichthyofaunal province (Miller et al. 2009). These findings are in accordance with a similar analysis carried out for helminth parasites of freshwater fish (Aguilar-Aguilar et al. 2008). This general pattern is also similar to that found for terrestrial vertebrates with the highest species richness in southeastern Mexico (Koleff \& Soberón 2008).

This centre has 44 families and 265 species, 16 of which are exotics. Within this group, the two most diverse families are Cichlidae and Poeciliidae with 42 and 40 species respectively. These are followed by the Gobiidae with 12 , Eleotridae 11, and Ariidae, Cyprinodontidae and Gerreidae with 10 species each. Perhaps due to the large river systems, availability of water and large floddplains (Aguilar 2003; Lara-Lara et al. 2008; Bunge 2010), there are species with large distributions, such as Sciades guatemalensis (34 grid cells), Astyanax aeneus (33) (Image 1), Cichlasoma urophthalmus (31), Poecilia mexicana (31), Gambusia yucatana (29), Belonesox belizanus (28), Rocio ocotal (28), Parachromis friedrichsthalii (27), Heterandria bimaculata (24) and Cichlasoma salvini (23). By contrast, there are 71 species with distributions represented by only one grid-cell equivalent to $12,345 \mathrm{~km}^{2}$.

(2) The second centre occurs in central Mexico mainly within the Lerma-Santiago river system, which corresponds to the central part of the Mesa Central ichthyofaunal province (Miller et al. 2009). It has eight grid-cells that range from 33-52 species per cell, with the highest values concentrated in the region of Michoacan lakes (Patzcuaro \& Cuitzeo) as well as Lake Chapala, which has been well documented previously (Domínguez-Domínguez et al. 2006b, Huidobro et al. 2006, Mercado-Silva et al. 2006). This province also corresponds with the findings of Aguilar-Aguilar et al. (2008) for fish helminths. It has 23 families and 122 species of freshwater fish, including 19 exotics. The most diverse family is Goodeidae with 25 species, but in the whole of the Mesa Central there are about 41 species (Domínguez-Domínguez et al. 2006a). Other diverse families are Atherinopsidae, Poeciliidae and Cyprinidae, 
with 22, 13 and 12 species respectively. The two species with the widest distribution (eight grid-cells) are Goodea atripinnis, and the exotic Oreochromis mossambicus. These are followed by a group of species with relatively wide distributions (seven grid-cells) such as Algansea tincella, Notropis sallaei, Chirostoma arge, Ilyodon whitei, Poeciliopsis infans, and the exotics Oreochromis aureus and Xiphophorus hellerii. The last species is native to Mexico but not to to the Mesa Central (Miller et al. 2009), following the definition proposed by Copp et al. (2005). In this region, there were 55 species having distributions within one grid-cell.

(3) The third center is localized in northern Mexico, along the border with the United States, and corresponds to the Bravo-Conchos river system. It comprises eight grid-cells that range from 32-57 species, the most diverse one of which includes the Rio Bravo delta and part of Laguna Madre. This suggests that its high diversity is a reflection of the influence of the presence of many peripheral fish species. It has 30 families and 122 species, with only three exotics. The three most diverse families are Cyprinidae, Poeciliidae and Cyprinodontidae with 24, 14 and nine species respectively. As in the previous region, species distributions range from 1-8 grid cells. There are five species with a wide distribution, Astyanax mexicanus, Gambusia affinis, Ictalurus punctatus, Lepomis macrochirus and Micropterus salmoides, all native to the region. However, 57 species have distributions which include only one grid-cell.

(iv) The fourth center is found in eastern Mexico along the central portion of the Gulf, and comprises the Pánuco and Tuxpan-Nautla rivers, the latter of which, corresponds to the Tamesi-Pánuco complex ichthyofaunal province. It consists of seven grid-cells with a range of $33-41$ species. It has 32 families and 125 species, 15 of which are exotics. The most diverse families are Poeciliidae and Cichlidae with 24 and 11 species respectively. Three species are distributed throughout the whole centre (seven grid-cells), Astyanax mexicanus, Poecilia Mexicana and Herichthys cyanoguttatus. In the case of this last species, Miller et al. (2009) suggested that for this region it could be a different species. There are also 53 species with distributions of only grid-cell.

There are three other grid-cells with relatively high

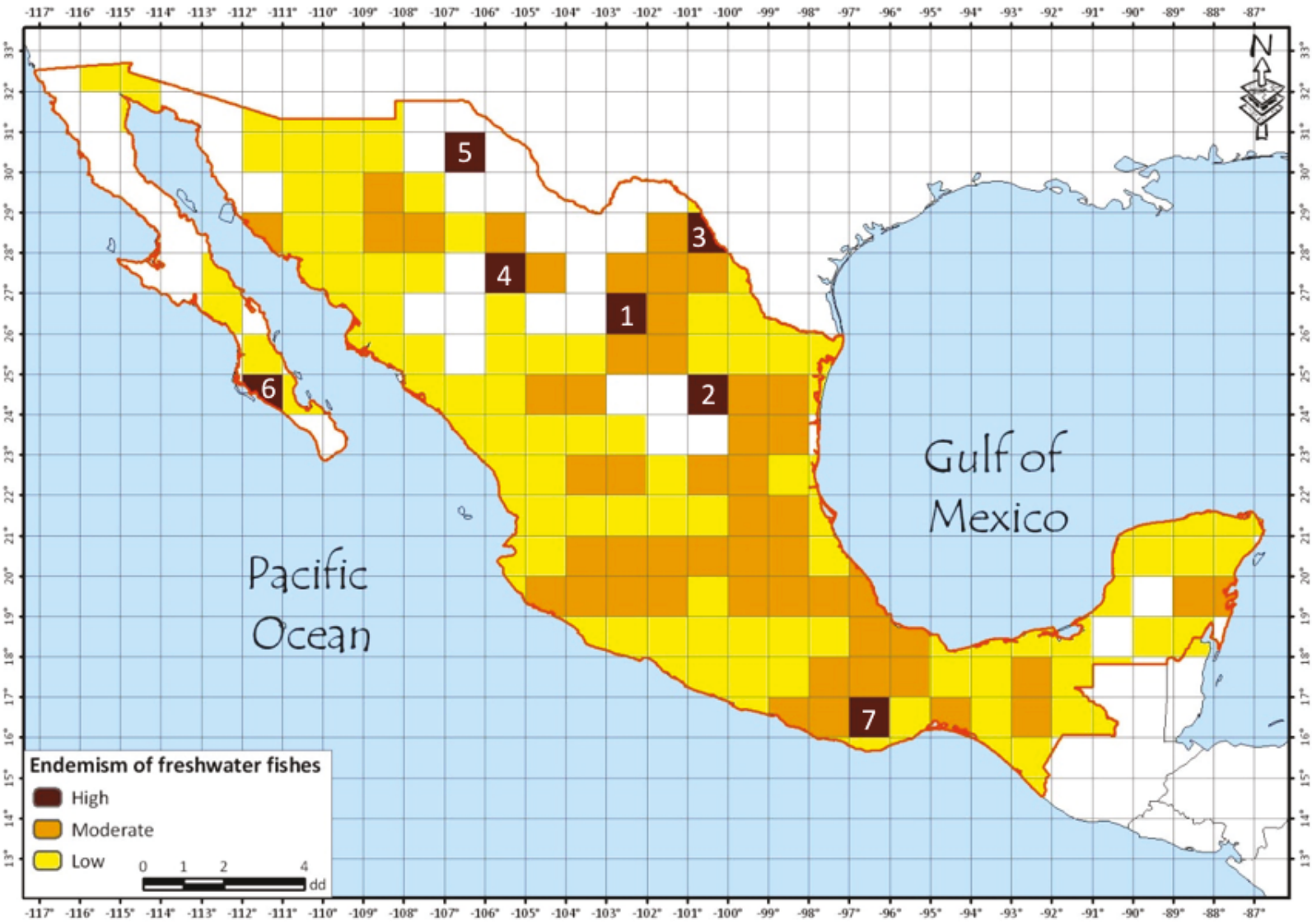

Figure 3. Centres of endemism for Mexican freshwater fish 
values of species richness, two are along the Pacific coast, one in Guerrero and the other in Sinaloa, but this reflects the influence of 'peripheral' fish species. One of the highlighted grid-cells has 33 species and is located in central Mexico between the States of Morelos and México reflecting the influence of the higher Lerma and Balsas basins. However, this high number of species is mainly due to the presence of 14 exotic species, which represent $42 \%$ of the total. Based on native species alone, this cell would fall in the low richness category with only 19 species. Exotics species account for 64\% of all species within the State of Morelos (ContrerasMacBeath et al. 1998).

\section{Endemism}

Based on the definitions applied here, Mexican endemics appear to be widely distributed across the country. Of the endemic species identified, 216 occurred within 174 of the 249 grid-cells (colored grid-cells Fig. 3) representing $70 \%$ of the country area. There were also areas of moderate endemism throughout the country, but with no distinctive pattern apparent.

Based on the calculated indices (CWEI) of endemism, seven individual grid-cells showed high values. These are highlighted in the map (dark color Fig. 3). Most occur in northern Mexico and are associated with arid ecosystems, areas of relatively low species richness and with species of restricted distributions. These grid-cells can be grouped in one of two categories. Grid-cells 1 and 2 can be considered as true centers of endemism.

The first center of endemism (Fig. 2(1)) compromises the valley of Cuatrociénegas in central Coahuila, which is a $1,000 \mathrm{~km}^{2}$ desert valley that has the greatest number of endemic species of any place in North America (Stein et al. 2000). Much of its biotic diversity is associated with a complex array of thousands of geothermal springs, marshes, lakes and streams (Souza et al. 2006). It has the highest richness of all the areas of endemism identified in this paper with 10 endemic fish species, but its high index of endemism is dependent on the presence of Cyprinella xanticara, Cyprinodon atrorus, Cyprinodon bifasciatus, Etheostoma lugoi, Gambusia longispinis, Herichthys minckleyi, Lucania interioris and Xiphophorus gordoni. This is one of the eight globally outstanding freshwater ecoregions identified for Mexico by Revenga et al. (2000).

The second center of endemism (Fig. 2(2)) consists of two springs included in two endorheic basins in Southwestern Nuevo León; El Potosí (Ejido Catarino Rodríguez, Municipio de Galeana), which is the type locality for Cyprinodon alvarezi and Megupsilon aprorus (both now extinct in the wild) and the Ojo de Agua la Presa in Bolsón de Sandia which was inhabited by Cyprinodon veronicae, Cyprinodon longidorsalis (both now extinct in the wild), Cyprinodon inmemoriam and Cyprinodon ceciliae (both extinct). Due to the fact that all six species identified for this center are extinct or extinct in the wild, it is best regarded as a "ghost" center of endemism. Eleven years ago, the freshwater ecosystems in this area, which roughly corresponds to "Llanos EI Salado" ecoregion were regarded as vulnerable by Abell et al. (2000) but have now all disappeared due to water abstraction. Clearly, further studies are required to identify the stressors which have contributed to the extinction of these species, to avoid similar problems occurring elsewhere. The remaining areas of endemism (compared to the valley of Cuatrociénegas and Llanos El Salado), are highlighted by values of CWEI due to the fact that they are in areas with low species richness of endemics, and those present have restricted distributions.

The third center (Fig. 3) occurs in the northern part of Coahuila, on the border with the United States. This center is defined by two species: Gambusia krumholzi from Río de Nava and Prietella phreatophila from a series of caves in the same region. Although both of these sites are found within part of the río Bravo basin, they are restricted to México.

Center (4) is triggered by Gambusia alvarezi, which is endemic to the Ojo de San Gregorio spring near Ciudad Parral Chihuahua and center (5) triggered by Cyprinodon fontinalis and Cyprinella bocagrande, both from Bolsón de los Muertos in Chihuahua. Center (6) is localized in

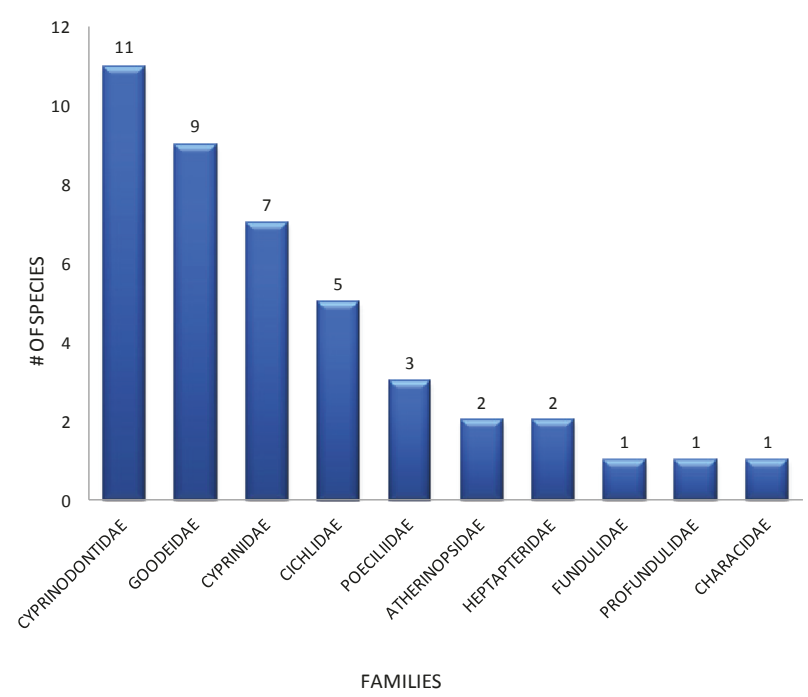

Figure. 4. Number of species per family for single site endemics. 
the Baja California Peninsula and is triggered by Gobiesox juniperoserrari, that is known only from a series of pools in Arroyo "Las Pocitas" in Baja California Sur. Center (7) is localized to the south of the country in Río Tehuantepec, Atoyac basin in the State of Oaxaca, and is triggered by two species, Notropis imelda and Poeciliopsis lutzi.

\section{Single site endemics}

In order to understand in detail the distribution of endemic species, we set out to identify species with discrete distributions known only from one site. From our analysis, we found that 43 species in 11 families can be regarded as single site endemics. The most diverse family is Cyprinodontidae with 11 species, followed by Goodeidae (9), Cyprinidae (7), Cichlidae (5), Poeciliidae (3), Atherinopsidae and Heptapteridae with two species each, and then there are three families with one species each (Fundulidae, Profundulidae and Characidae) (Fig. 4).

Single site endemics are distributed all over the country (Fig. 5). Some species have a very restricted distribution; for example Zoogoneticus tequila (Image 2) is now only found in a $4 \mathrm{~m}$ diameter spring in Tehuchitlán Jalisco (De la Vega-Salazar et al. 2003) and Cyprinodon julimes from the Chihuahuan desert that occurs in a $742 \mathrm{~m}^{2}$ thermal spring (De la Maza et al. 2010). Others localized endemics are found in larger water bodies such as Bramocharax caballeroi restricted to Catemaco Lake in Veracruz with a surface area of $72.54 \mathrm{~km}^{2}$ (Torres-Orozco \& Sanatta 1998). There are also other local endemics such as Poeciliopsis catemaco and Xiphophorus milleri which occur in Lake Catemaco, but these were not considered because they can also be found in streams and tributaries of the lake (Miller et al. 2009).

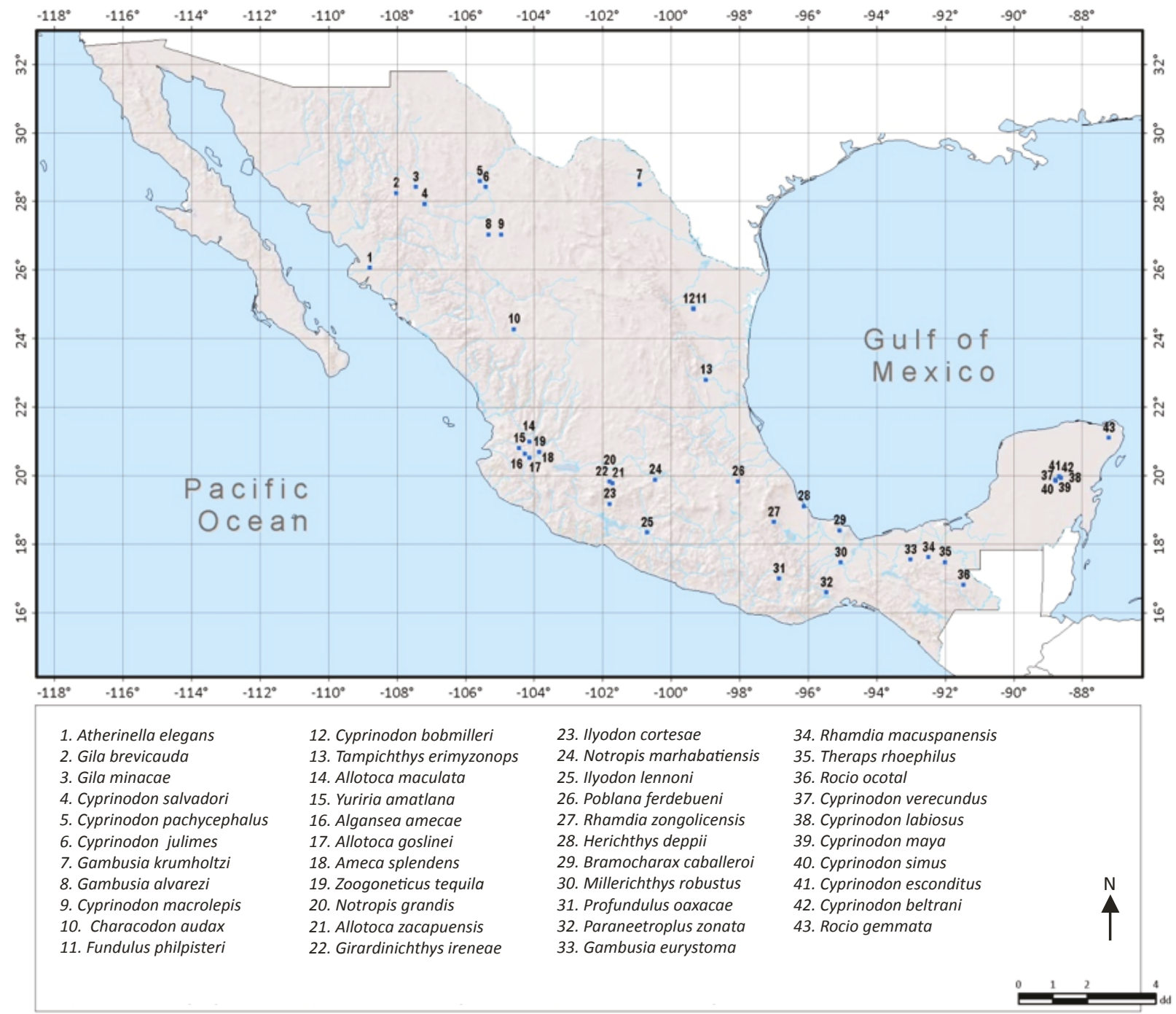

Figure 5. Map showing records for single site endemic freshwater species in Mexico. 
It is important to mention a species flock composed of six endemic species of Cyprinodonts (Cyprinodon beltrani, C. simus, C. maya, C. labiousus, C. esconditus $\&$ C. verecundus) occurs in Laguna Chichancanab in the border between Yucatan and Quintana Roo (GarcíaMoreno et al. 2008), but their occurrence could not be identified by the methods used here CWEI method (Crisp et al. 2001). There is also a small region in centralwestern Mexico, where there are several endemic species of the upper Río Ameca, (Yuriria amatlana, Allotoca goslinei, Algansea amecae, Ameca splendens and Zoogoneticus tequila) which could be treated as a center of endemism. The last species mentioned above is now confined to a single small spring in Tehuchitlan Jalisco (De la Vega-Salazar et al. 2003; Magurran 2009).

\section{Richness and endemism hotspots}

In order to identify biodiversity hotspots (Myers 1988; Crisp et al. 2001; Aguilar-Aguilar et al. 2008; Myers et al. 2000), richness and endemism were correlated and a map constructed (Fig. 6). Three main hotspots with high values; (1) the Mesa Central, (2) the Centralsoutheastern and (3) the Lower Rio Bravo River were identified. These are aso priority areas for conservation in terms of their parasite biodiversity and threats by Aguilar et al. (2010).

Among these, the Mesa Central stands out and includes the headwaters of the Río Ameca and the Lerma-Chapala-Santiago system extending into the Río Pánuco basin. This whole region includes four of the eight globally outstanding freshwater ecoregions described by Revenga et al. (2000) that are distributed along central Mexico. This region has been described as transitional between the Nearctic and Neotropical provinces (Morrone 2005; Huidobro et al. 2006; Corona et al. 2007) and contributes to its high species richness and endemism for fish (Miller 2005). Within this region, two hotspots can be identified which have the highest value for the combination of richness and endemism.

The first hotspot, consists of an area known as the "Bajo Lerma" (Díaz-Pardo et al. 1993) and includes headwaters of the Río Ameca and Lake Chapala. It has 48 species of which 38 are Mexican endemics (79\%). The second hotspot is formed by two adjacent grid-cells that cover the "Medio Lerma", including lakes Patzcuaro, Cuitzeo and Yuridia. It has 63 species, of which 49 are

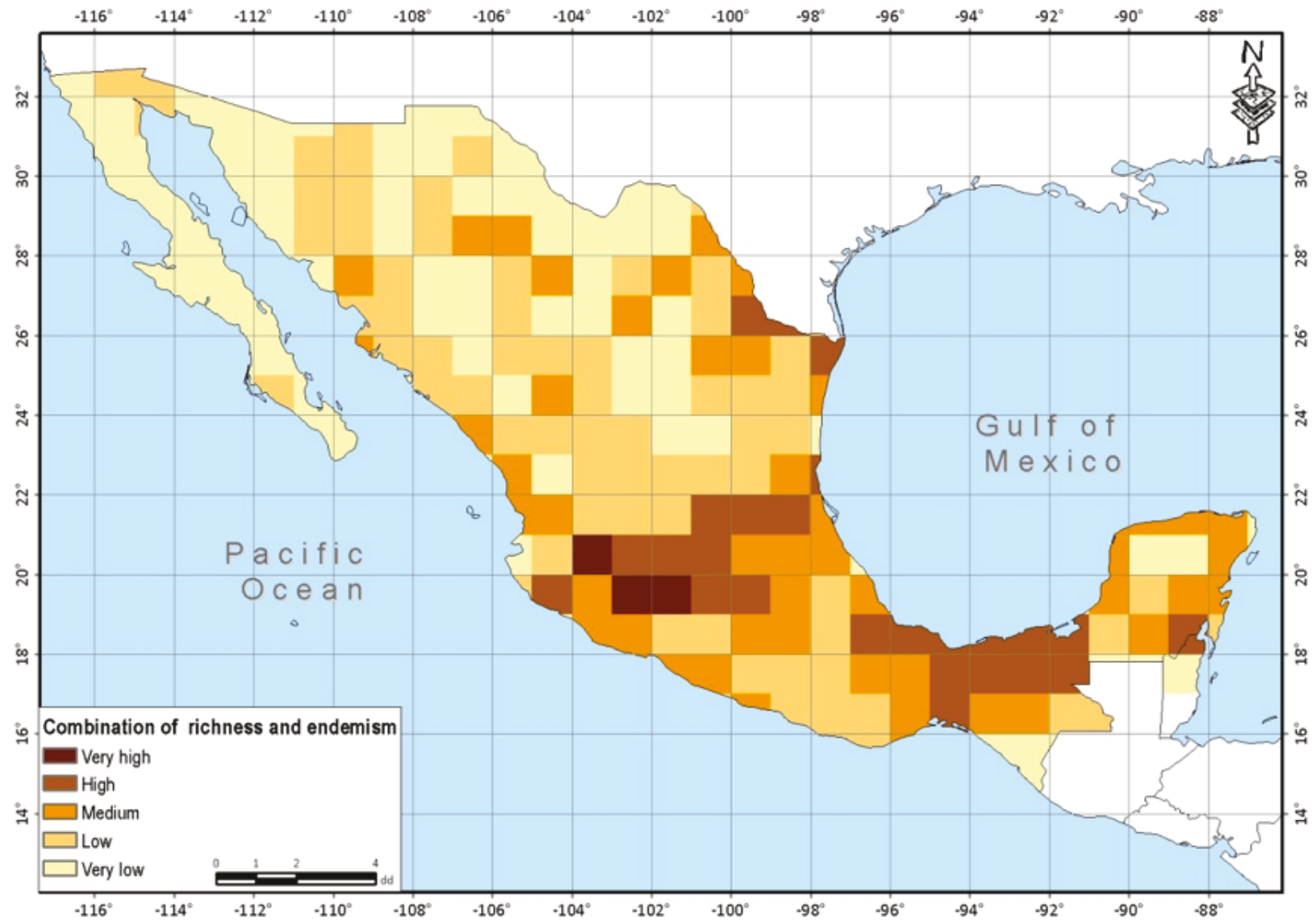

Figure 6. Hotspots of richness and endemism for the freshwater fishes of Mexico. 

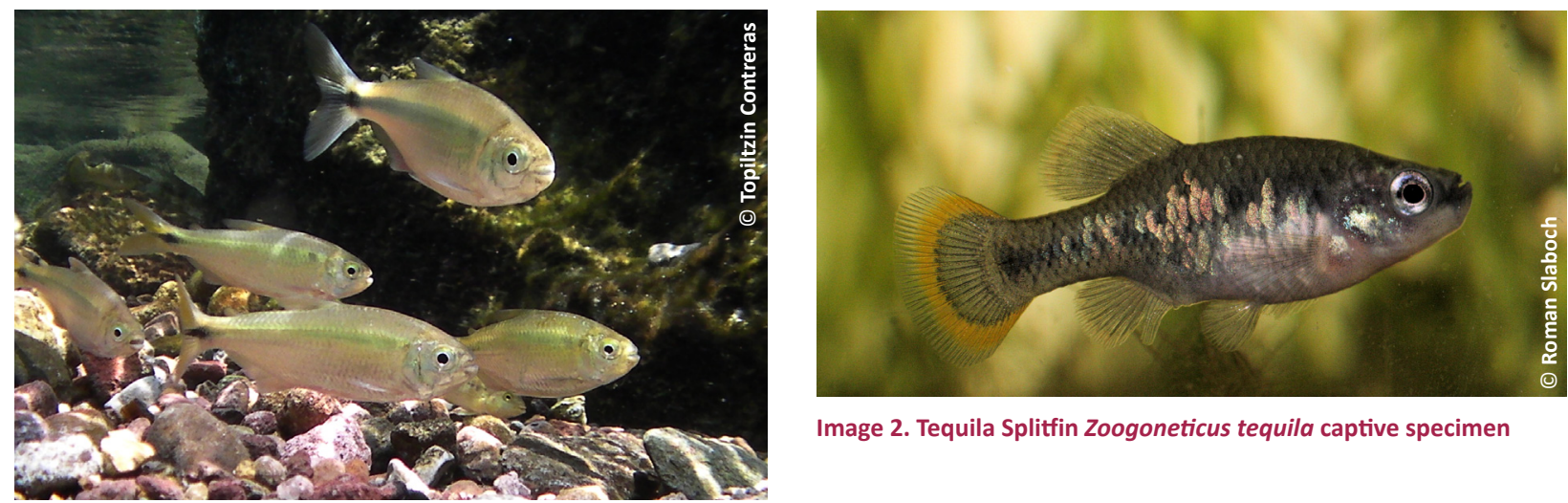

Image 2. Tequila Splitfin Zoogoneticus tequila captive specimen

Image 1. Astyanax aeneus (Platilla) from Agua Salada Spring in Morelos State

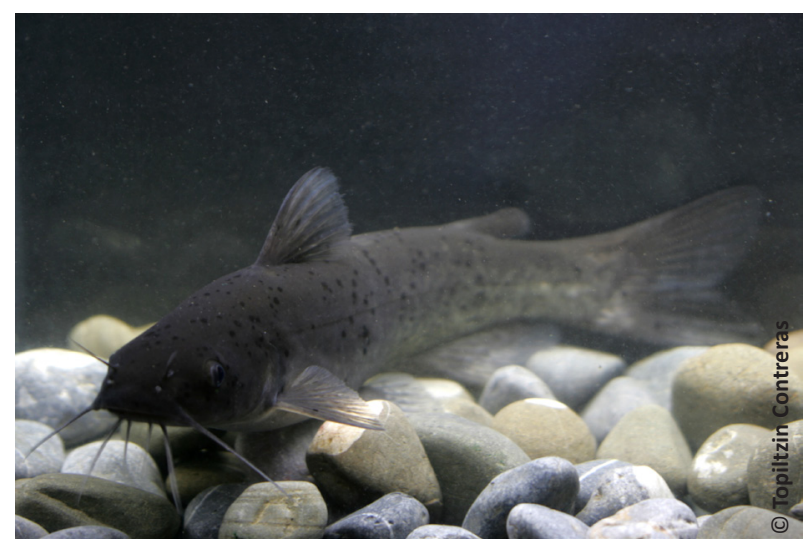

Image 3. Ictalurus balsanus (Balsas River Catfish) captive specimen from the Ichthyology laboratory
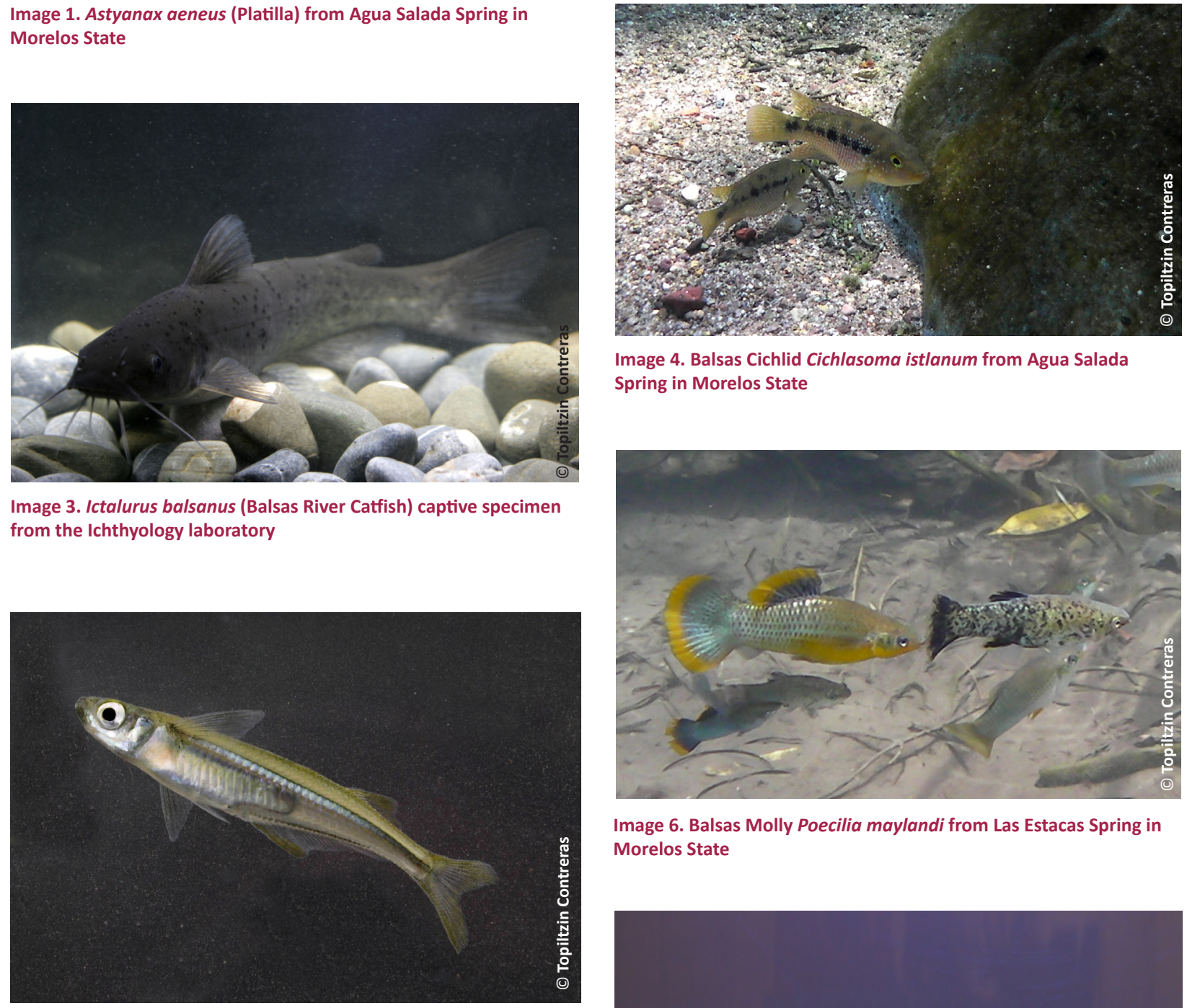

Image 4. Balsas Cichlid Cichlasoma istlanum from Agua Salada Spring in Morelos State

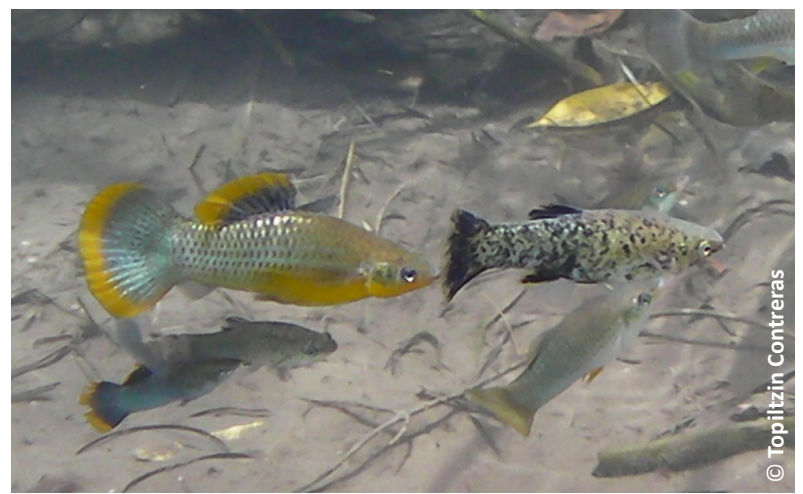

Image 6. Balsas Molly Poecilia maylandi from Las Estacas Spring in Morelos State

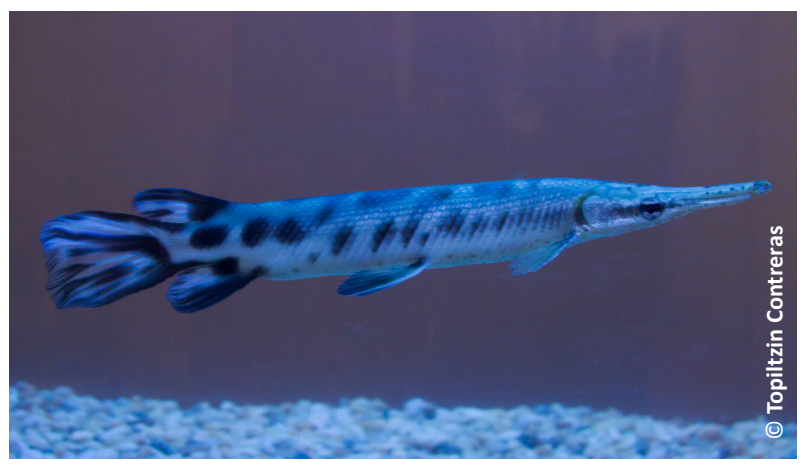

Image 7. Captive specimen of Spotted Gar Lepisoteus oculatus 
Mexican endemics (77\%). Unfortunately, this region of Mexico has also been identified as one of the most seriously downgraded/impacted areas (rivers and lakes) by human activities (Bernal-Brooks 1998; Fisher et al. 2003; von Bertrab, 2003; Garrido et al. 2010). This has had a negative impact on the native fish fauna of the region (De la Vega-Salazar 2006; DomínguezDomínguez et al. 2006a; Domínguez-Domínguez et al. 2008; Mercado-Silva et al. 2009; Magurran 2009) and has resulted in the extinction of six species, namely Chirostoma bartoni, Chirostoma charari, Evarra bustamantei, Evarra eigenmanni, Evarra tlahuacensis and Skiffia francesae (Contreras-MacBeath 2005).

The Central-southeastern hotspot includes the area with most water resources in Mexico for the rivers Coatzacoalcos, Papaloapan and Grijalva-Usumacinta (CONAGUA 2008; Bunge 2010). This hotspot is more relevant because of its richness of 208 species, rather than its endemics comprising of only 30 species (14.4\%). Maybe due to the abundance of water in this hotspot, as well as the relatively low human population, it is one of Mexico's regions with lowest pollution as indicated by measures of Biochemical Oxygen Demand (BOD) and Chemical Oxygen Demand (COD) (CONAGUA 2010). Nevertheless, Rio Grijalva is highlighted as an area that has witnessed large habitat modifications due to the construction of four large dams (Garrido et al. 2000). There are als two known extinct species in this hotspot namely Atherinella callida, Priapella bonita (Harrison \& Stiassny 1999).

The last of the hotspots identified is a small area in northern Mexico that corresponds to the lower Rio Bravo. As in the former case, this hotspot is highlighted mainly by its richness of 90 species, rather than the occurrence of seven endemics (7.7\%). As with many Mexican freshwater ecosystems associated with arid regions, it has been severely impacted by human activities (Contreras-Balderas \& Lozano-Vilano 1993). Surveys have demonstrated that the original freshwater fish fauna has been retreating from the lower reaches and is being replaced by brackishwater and marine invaders (Contreras-Balderas et al. 2002). This river which had a runoff of over 12,000 million cubic meters/ year in 1962 had less than 2\% of that figure in 2002 and was dry for months in the delta region, both in 2002 and 2004 (Contreras-Balderas et al. 2008).

\section{CONCLUSIONS}

Data on species richness and endemism are both crucial for identifying regional and national 'hotspots' and for directing conservation effort. Identifying and mapping these centres by means of geographical information systems based on museum data have confirmed several previously identified centres of freshwater fish richness including those of southeastern Mexico, the Mesa Central, the Bravo-Conchos river system and the Panuco and Tuxpan-Nautla rivers. A further seven areas with high CWEl endemism values have been identified including the valley of Cuatrociénegas recognized as a true centre. Unfortunately, an important area previously identified as a center of endemism, has now been identified as a "Ghost" centre of endemism (Llanos El Salado) in southwestern Nuevo León, due to the loss of six endemic cyprinodont species that were previously present in this area. In addition, 49 single location endemics were found to be widely dispersed across Mexico. One site, the Chichancanab lagoon on the border between Yucatan and Quintana Roo, contains a flock of six endemic cyprinodonts. Many of the other single site endemics which are threatened species should be considered as areas triggering 'Alliance for Zero Extinction'. However, three hotspots of richness and endemism in Mexico including the Mesa Central have been seriously compromised by human activities that are very detrimental to fish species populations.

This study has provided a countrywide analysis of the distributional patterns of most of the known species of freshwater fish in Mexico, using the most up-to-date information available. However, further work is required on a smaller scale to identify and resolve local conservation issues. However, our results, provide important baseline reference material which can stimulate further conservation initiatives and debate at both local and national level. The next step is to complete the IUCN threat assessments for each species. When completed, it will be possible to crossreference our findings with the distributional patterns of threatened species and define explicit conservation goals. Our study has also shown that methods, which have previously been applied to terrestrial taxa, can also be applied successfully to aquatic taxonomic groups.

\section{REFERENCES}

Abell, R.A., D.M. Olson, E. Dinerstein, P. T. Hurley, J. T. Diggs, L.L.B.W. Eichbaum, M.S.S. Walters, M.C.P.W. Wettengal, M.S.T. Allnutt, M.E.M.C.J. Loucks \& P. Hedao (2000). Freshwater Ecoregions of 
North America: A Conservation Assessment. Washington, DC, Island, 319pp.

Aguilar, V. (2003). Aguas continentales y diversidad biológica de México: un recuento actual. Biodiversitas 8(48): 1-15.

Aguilar, V., M. Kolb, P. Koleff \& T.U. Haas (2010). Las cuencas de México y su biodiversidad: una visión integral de las prioridades de conservación, pp. 142-153. In: Cotler A.H. (coordinadora). Las cuencas hidrográficas de México: Diagnóstico y priorización. SEMARNAT-INE- FGRA. Printed in México.

Aguilar-Aguilar, R., G. Salgado-Maldonado, R. Contreras-Medina \& A. Martínez-Aquino (2008). Richness and endemism of helminth parasites of freshwater fishes in Mexico. Biological Journal of the Linnean Society 94(2): 435-444; http://dx.doi.org/10.1111/j.10958312.2008.00994.x

Bell, G. (2001). Neutral macroecology. Science 293(5539): 2413-2418; http://dx.doi.org/10.1126/science.293.5539.2413

Bernal-Brooks, F.W. (1998). The lakes of Michoacán (Mexico): a brief history and alternative points of view. Freshwater Forum 10: 20-34.

Berra, T.M. (2007). Freshwater Fish Distribution. The University of Chicago Press, Chicago and London, 606pp.

Bunge, V. (2010). La disponibilidad natural de agua en las cuencas de México, pp. 46-49. In: Cotler A.H. (ed.). Las cuencas hidrográficas de México: Diagnóstico y priorización. SEMARNAT-INE- FGRA. Printed in México.

Ceballos, G. (2001). Especies raras, el conocimiento de la diversidad biológica y la conservación. Biodiversitas (9-13). CONABIO, Mexico.

CONABIO (1998). La diversidad Biológica de México: estudio de país, 1998. Comisión Nacional para el Conocimiento y Uso de la Biodiversidad, México.

CONAGUA (2008). Estadísticas del Agua en México 2008. Secretaría de Medio Ambiente y Recursos Naturales, Mexico City, 227pp.

CONAGUA (2010). Statistics on water in México 2010. México, D.F., 258pp.

Contreras-Balderas, S., Ruiz, G., Campos, J. J., Schmitter-Soto, E. D., Pardo, T. Contreras-McBeath, M. Medina-Soto, L. ZambranoGonzález, A. Varela-Romero, R. Mendoza-Alfaro, C. RamíreaMartínez, M. A. Leija-Tristán, P. Almada-Villela, D.A Hendrickson \& J. Lyons (2008). Freshwater fishes and water status in Mexico: a country-wide appraisal. Aquatic Ecosystem Health and Management 11(3): 246-256.

Contreras-Balderas, S. \& M.L. Lozano-Vilano (1993). Water, Endangered Fishes, and Development Perspectives in Arid Lands of México. Conservation Biology 8(2): 379-387; http://dx.doi. org/10.1046/j.1523-1739.1994.08020379.x

Contreras-Balderas, S., R.J. Edwards, M. Lozano-Vilano \& M. GarcíaRamírez (2002). Fish biodiversity changes in the lower Rio Grande/ Rio Bravo, 1953-1996. Reviews in Fish Biology and Fisheries 12: (23): 219-240; http://dx.doi.org/10.1023/A:1025048106849

Contreras-MacBeath, T. (2005). Fish conservation in Mexico with emphasis in livebearing species, pp. 401-414. In: Uribe, M.C. \& H. J. Grier (eds.). Viviparous Fishes. New Life Publishers.

Contreras-MacBeath, T. (2014). PhD Thesis Manchester Metropolitan University, Manchester UK.

Contreras-MacBeath, T., H. Mejia \& R.W. Carrillo (1998). Negative impact on the aquatic ecosystems of the state of Morelos from introduced aquarium and other commercial fish Aquarium Sciences and Conservation 2(2): 67-78; http://dx.doi. org/10.1023/A:1009676403693

Copp, G.H., P.G. Bianco, N.G. Bogutskaya, T. Eros, I. Falka, M.T Ferreira, M.G. Fox, J. Freyhof, R.E. Gozlan, J. Grabowska, V. Kovac' R. Moreno-Amich, A.M. Naseka, M., Peñaz, M. Povz, M. Przybylski, M. Robillard, I.C. Russell, S. Stakenas, S. Sumer, A. Vila-Gispert \& C. Wiesner (2005). To be, or not to be, a non-native freshwater fish? Journal of Applied Ichthyology 21(4): 242-262; http://dx.doi. org/10.1111/j.1439-0426.2005.00690.x

Corona, A.M., V.H. Toledo \& J.J. Morrone (2007). Does the TransMexican Volcanic Belt represent a natural biogeographic unit? An analysis of the distribution patterns of Coleoptera. Journal of Biogeography 34(6): 1008-1015; http://dx.doi.org/10.1111/j.1365- 2699.2006.01666.x

Crisp, M.D., S. Laffan, H.P. Linder \& A. Monro (2001). Endemism in the Australian flora. Journal of Biogeography 28(2): 183-198; http:// dx.doi.org/10.1046/j.1365-2699.2001.00524.x

Darwall, W.R.T., K.G. Smith, D.J. Allen, R.A. Holland, I.J. Harrison \& E.G.E. Brooks (eds.) (2011). The Diversity of Life in African Freshwaters: Under Water, Under Threat. An Analysis of the Status and Distribution of Freshwater Species Throughout Mainland Africa. Cambridge, United Kingdom and Gland, Switzerland: IUCN. xiii+347pp+4pp cover.

De la Maza, M., J. Hoth, A. Rodríguez, H. Parra \& L. Vela (2010). Rescate del cachorrito de Julimes, pp. 46-47. In: Carabias J., et al. (coords.). Patrimonio natural de México. Cien casos de éxito. México, Comisión Nacional para el Conocimiento y Uso de la Biodiversidad.

De la Vega-Salazar, M.Y. (2006). Estado de conservación de los peces de la familia Goodeidae (Cyprinodontiformes) en la mesa central de México. Revista de Biologica Tropical 54(1): 163-177

De La Vega-Salazar, M.Y., E.G. Avila-Luna \& C. Macías-Garcia (2003). Threatened fishes of the world: Zoogoneticus tequila Webb \& Miller 1998 (Goodeidae). Environmental Biology of Fishes 68(1): 14; http:// dx.doi.org/10.1023/A:1026040727808

Díaz-Prado, E., M.A. Godines-Rodriguez, E. López-López \& E. SotoGalera (1993). Ecología de los peces de la cuenca del río Lerma, México. Analales Escuela. Nacional Ciencias Biológicas México 39: 103-127.

Domínguez-Domínguez, O., I. Doadrio \& G. Pérez-Ponce de León (2006a). Historical biogeography of some river basins in Central Mexico evidenced by their goodeine freshwater fishes: A preliminary hypothesis using secondary Brooks Parsimony Analysis (BPA). Journal Biogeography 33(8): 1437-1447; http://dx.doi. org/10.1111/j.1365-2699.2006.01526.x

Dominguez-Dominguez, O., E. Martinez-Meyer, L. Zambrano \& G.P.P. De Leon (2006b). Using ecological-niche modeling as a conservation tool for freshwater species: live-bearing fishes in central Mexico. Conservation Biology 20(6): 1730-1739; http://dx.doi.org/10.1111/ j.1523-1739.2006.00588.x

Domínguez-Domínguez, O., L. Zambrano, L.H. Escalera-Vázquez, R. Pérez-Rodríguez \& G. Pérez-Ponce De León (2008). Cambio en la distribución de goodeidos (Osteichthyes: Cyprinodontifornes: Goodeidae) en cuencas hidrológicas del Centro de México. Revista Mexicana de Biodiversidad 79: 505-516.

Espinosa, D., S. Ocegueda C. Aguilar, O. Flores \& J. LlorenteBousquets (2008). El conocimiento biogeográfico de las especies y su regionalización natural, en Capital natural de México, vol. I: Conocimiento actual de la biodiversidad. Conabio, México, 33-65pp.

Flores-Villela, O. \& P. Gerez (1994). Biodiversidad y conservación en México: vertebrados, vegetación y uso del suelo. Conabio-unam, México.

Froese, R. \& D. Pauly (eds). (2006). FishBase. World Wide Web electronic publication. www.fishbase.org. Consulted (06/2006).

García-Moreno, J., A. Upgren, J.I. Restrepo, W. Matamoros, A.D. Cuarón, T. Contreras-MacBeath, N. López, J. Lamoreux , M. McKnight, A. Muñoz, P. Walker, J. Townsend, C. Vásquez-Almazán, C. Macías, O. Komar, J. Barborak, R. Jiménez \& J. R. Bonilla-Barbosa (2008). Los sitios más críticos para evitar extinciones de especies globalmente amenazadas: la importancia de su identificación y de recabar información en el campo. Mesoamericana 11(4): 59-63.

Garrido, A., M.L. Cuevas, H. Cotler, D.I. González \& R. Tharme (2010). El estado de alteración ecohidrológica de los ríos de México, pp. 108-111. In: Cotler A.H. (ed.). Las cuencas hidrográficas de México: Diagnóstico y priorización. SEMARNAT-INE- FGRA. Printed in México.

Gaston, K.J. (1998). Species-range distributions: products of speciation, extinction and transformation. Philosophical Transactions of the Royal Society of London B, Biological Sciences 353(1366): 219-230; http://dx.doi.org/10.1098/rstb.1998.0204

Gozlan, R.E., J.R. Britton, I.G. Cowx \& G.H. Copp (2010). Current knowledge on nonnative freshwater fish introductions. Journal of Fish Biology 76(4): 751-786; http://dx.doi.org/10.1111/j.10958649.2010.02566.x 
Harrison, I.J. \& M.L.J. Stiassny (1999). The quiet crisis a preliminary listing of the freshwater fishes of the world that are extinct or "missing in action", pp. 271-331. In: McPhee, R. (ed.). Extinctions in Near Time. Kluwer Academic/Plenum Publishers.

Huidobro, L., J.J. Morrone, J.L. Villalobos \& F. Alvarez (2006). Distributional patterns of freshwater taxa (fishes, crustaceans and plants) from the Mexican Transition Zone. Journal of Biogeography 33(4): 731741; http://dx.doi.org/10.1111/j.1365-2699.2005.01400.x

Jetz, W. \& C. Rahbek (2002). Geographic range size and determinants of avian species richness. Science 297(5586): 1548-1551; http://dx.doi.org/10.1126/science.1072779

Koleff, P. \& J. Soberón (2008). Patrones de diversidad espacial en grupos selectos de especies, pp. 323364. In: Capital natural de México, vol. I: Conocimiento actual de la biodiversidad. Conabio, México.

Lara-Lara, J.R., V. Arenas, C. Bazán, V. Díaz, E. Escobar, M. Cruz, G. Gaxiola, G. Robles, R. Sosa, L. Soto M. Tapia \& E. Valdez-Holguín (2008). Los ecosistemas costeros, insulares y epicontinentales, pp. 109134. In: Koleff, P., J. Soberón et al. (eds.). Capital natural de México, vol. I: Conocimiento actual de la biodiversidad. Comisión Nacional para el Conocimiento y Uso de la Biodiversidad, Mexico City.

Lévêque, C., T. Oberdorff, D. Paugy, M.L.J. Stiassny \& P.A. Tedesco (2008). Global diversity of fish (Pisces) in freshwater. Hydrobiologia 198: 545-567; http://dx.doi.org/10.1007/978-1-4020-8259-7_53

Linder, H.P. (2001). Plant diversity and endemism in sub-Saharan tropical Africa. Journal of Biogeography 28(2): 169-182; http://dx.doi.org/10.1046/j.1365-2699.2001.00527.x

Magurran, A.E. (2009). Threats to freshwater fish. Science 325(5945): 1215-1216; http://dx.doi. org/10.1126/science.1177215

Mercado-Silva, N., J. Lyons, E. Díaz-Pardo, A. Gutiérrez-Hernández, C.P. Ornelas-García, C. Pedraza-Lara \& M.J.V. Zanden (2006). Long-term changes in the fish assemblage of the Laja River, Guanajuato, central Mexico. Aquatic Conservation: Marine and Freshwater Ecosystems 16(5): 533-546; http://dx.doi. org/10.1002/aqc.737

Mercado-Silva, N., M.R. Helmus \& M.J.V. Zanden (2009). The effects of impoundment and invasive species on a river food web in Mexico's central plateau. River Research and Applications 25(9): 10901108; http://dx.doi.org/10.1002/rra.1205

Miller, R.R. (2005). Freshwater Fishes of México. The University of Chicago Press, 490pp.

Miller, R.R., W.L. Minckley \& S.M. Norris (2009). Peces dulceacuícolas de México. Comisión Nacional para el Conocimiento y Uso de la Biodiversidad, Sociedad Ictiológica Mexicana, El Colegio de la Frontera Sur, Desert Fishes Council, Mexico City, 559pp.

Mittermeier, R.A., T.M. Brooks, T.A. Farrell, A.J. Upgren, I.J. Harrison, T. Contreras-MacBeath, R. Sneider, F. Oberfeld, A.A. Rosenberg, F. Boltz, C. Gascon \& O. Langrand (2010). Introduction. Fresh water: the essence of life. In: Fresh Water: The Essence of Life. CEMEX and ILCP, 299pp.

Morrone, J.J. (2005). Hacia una síntesis biogeográfica de México. Revista Mexicana de Biodiversidad 76: 207-252.

Myers, G.S. (1949). Salt-tolerance of fresh-water fish groups in relation to zoogeographical problems. Bijdragen tot de Dierkunde 28: 315-322.

Myers, G.S. (1966). Derivation of the freshwater fish fauna of Central America. Copeia 1966(4): 766-773.

Myers, N., R.A. Mittermeier, C.G. Mittermeier, G.A.B. da Fonseca \& J. Kent (2000). Biodiversity hotspots for conservation priorities. Nature 403: 853-858; http://dx.doi.org/10.1038/35002501

Myers, N. (1988). Threatened biotas: 'hotspots' in tropical forests. Environmentalist 8(3): 187-208; http:// dx.doi.org/10.1007/BF02240252

Myers, N. (1990). The biodiversity challenge: expanded hot-spot analysis. Environmentalist 10(4): 243256; http://dx.doi.org/10.1007/BF02239720

Myers, N. (2003). Biodiversity hotspots revisited. BioScience 53: 916-917.

Nogueira, C., P.A. Buckup, N.A. Menezes, O.T. Oyakawa, T.P. Kasecker, M.B.R. Neto \& J.M.C. da Silva (2010). Restricted-range fishes and the conservation of Brazilian freshwaters. PloS one 5(6): e11390; http://dx.doi.org/10.1371/journal.pone.0011390

Ramamoorthy, T.R., R. Bye, A. Lot \& J. Fa (eds.). (1993). Biological Diversity of Mexico: Origins and Distribution. Oxford University Press, Nueva York.

Revenga, C., J. Brunner, N. Henninger, K. Kassem \& R. Payne (2000). Pilot Analysis of Global Ecosystems: Freshwater Systems. World Resources Institute, Washington DC., 78pp.

Souza, V., L. Espinosa-Asuar, A.E. Escalante, L.E. Eguiarte, J. Farmer, L. Forney, L. Lloret, J.M. RodríguezMartínez, X. Soberón, R. Dirzo \& J.J. Elser (2006). An endangered oasis of aquatic microbial biodiversity in the Chihuahuan desert. Proceedings of the National Academy of Sciences 103(17): 6565-6570; http:// dx.doi.org/10.1073/pnas.0601434103

Stein, B.A., L.S. Kutner \& J.S. Adams (eds.) (2000). Precious Heritage: The Status of Biodiversity in the United States. Oxford University Press, Oxford, 432pp.

Torres-Orozco, R. \& S.A. Zanatta (1998). Species composition, abundance and distribution of zooplankton in a tropical eutrophic lake: Lake Catemaco, México. Revista Biología Tropical 46: 285-296.

von Bertrab, E. (2003). Guadalajara's water crisis and the fate of Lake Chapala: A reflection of poor water management in Mexico. Environment and Urbanization 15(2): 127-140; http://dx.doi. org/10.1177/095624780301500204
Author Contribution: Topiltzin ContrerasMacBeath coordinated the study and participated in each step. C.R. Goldspink, and Gordon McGregor Reid participated in the design, management and implementation of the study, its research objectives and the provision of academic rigour. Marlem Brito Rodríguez participated in spatial analysis, integration of the freshwater fish data base of Mexico, richness map, endemism map and final cartography. Valentino Sorani participated in spatial analysis methodology development and manuscript revision.

Author Details: TOPILTZIN CONTRERAS is head of the Conservation Biology Research Group at the "Universidad Autónoma del Estado de Morelos" in Mexico, he is also Chair of the IUCN/SSC Freshwater Conservation Sub-Committee, he is also currently Minister for Sustainable Development of the Government of Morelos, Mexico. C.R.GoLDSPINK, previously worked for the International Biological Programme (Netherlands) Freshwater Section but currently involved with local and worldwide conservation issues. Particular research interests include the management of isolated lakes in North West England and the potential threats from invasive species and climatic change. Senior Lecturer at the Manchester Metropolitan University. GORDON MCGREGOR REID is the former Director General Director of Chester Zoo, and Former Chair of the IUCN/SSC Freshwater Fish Specialist Group. VALENTINO SORANI is head of the Interdisciplinary GIS Laboratory of the Research Center in Biodiversity and Conservation of the “Universidad Autónoma del Estado de Morelos". Professor of GIS. Expert in land planning, remote sensing and spatial analysis. MARLEM BRITO RODRÍGUEZ is responsible for the GIS area of the Interdisciplinary GIS Laboratory of the Research Center in Biodiversity and Conservation of the "Universidad Autónoma del Estado de Morelos". She is an expert in remote sensing, cartography and spatial data bases. 